\title{
Strengthening of Religious Character in Indonesia through Wayang Golek Santri
}

\author{
Marzuki $^{1}$, Samsuri $^{2}$, A Istiqomah ${ }^{3}$ \\ Faculty of Social Science, Universitas Negeri Yogyakarta, Yogyakarta, Indonesia ${ }^{123}$ \\ marzuki@uny.ac.id¹, samsuri@uny.ac.id², annisa.istiqomah@uny.ac.id³
}

\begin{abstract}
One of the causes of the deviant behavior that is affecting countries in the world including in Indonesia is due to the low level of individual religiosity. Wayang golek santri performances are expected to be one of the alternatives in strengthening religious character and become an appropriate medium in the community. This research was a content analysis research which used a qualitative approach. The object of research in this study was divided into two, namely primary and secondary objects. Data collection was carried out by using audio-visual techniques, documentation, and observation. Furthermore, the data was checked by the source triangulation validity checking technique. Data were analyzed using a qualitative approach by Miles and Huberman's model. The results showed that the strengthening of religious characters contained in dramatic conventions (language structure and character patterns) and central conventions (time and place, equipment used, how to play, and gamelan or accompaniment songs) in wayang golek santri show.
\end{abstract}

Keywords: wayang, character, religious

\section{Introduction}

In the last few years, there has been a lot of moral degradation in various parts of the world. According to Darmiati, moral degeneration, deviant attitudes and behavior are forms of various problems that occur in the community which are marked by the emergence of attitudes such as pragmatism, materialism, individualism, and hedonism [1]. This moral degradation causes various deviant behavior of individuals, for example it can be seen from acts of bullying, sexual violence, theft, persecution, and even many events that lead to the loss of one's life. Sadly, some cases that occurred involved students who were also students. Reporting from the online media BBC News Indonesia, there was a shooting case at Saugus High School in Santa Clarita, California, United States that left two people dead and three others injured. The shooting was carried out a few minutes before the learning activities took place by a 16-year-old boy [2]. Meanwhile in Indonesia, there are many cases of bullying that involve students and occur in the school environment.

The incident was quoted by Kompas.com online media which summarizes the four acts of bullying that occurred in several regions in Indonesia which caused physical and psychological injury to the victims [3]. Some of these cases are a portrait of the rampant juvenile delinquency that occurs in the community. One of the causes of the increase in deviant behavior is the low level of individual religiosity. The relationship between the low attitude of religiosity with deviant behavior raised by Welch, et.al which explains that religion plays a role in bridging behavior in society [4]. Putnam \& Campbell explains that religion develops its influence in shaping the understanding of social behavior that can be accepted through communal beliefs, systems of meaning, morals, and shared values [5]. Religious is an 
obedient attitude in carrying out the demands of the religion they adhere to, tolerance of followers of other religions, and living in harmony with other religions [6]. In contrast to Hasan, Glock and Stark revealed there are five dimensions of religiosity, namely: a) religious practice (the ritualistic dimension); b) Religious belief (the ideological dimension); c) Religious knowledge (the intellectual dimension); d) Religious feeling (the experiential dimension); e) Religious effect (the consequential dimension) [7]. The Guidelines for Strengthening Character Education which explains that religious contains the sub-values of this religious character include love for peace, tolerance, respect for differences in religion and beliefs, firm stand, self-confidence, mutual cooperation between followers of religion and belief, anti-bully and violence, friendship, sincerity, caring for others or not implementing self-will, caring for the environment, protect the small and excluded [8].

Efforts to strengthen religious character are basically part of strengthening the character education launched by the government. The Ministry of Education and Culture implements strengthening the character of the nation's successors through the Strengthening Character Education (PPK) movement which was rolled out since 2016 [9]. In order to create a synergistic climate, the effort to strengthen this religious character is carried out through the activities of the community itself, namely through collaborative activities with communities outside of educational institutions. One of the efforts is to increase the potential role of local wisdom through puppet show wayang golek performances which were initiated by Ki Enthus Susmono. The wayang golek santri media is used as one of the media in Strengthening Character Education in Brebes Regency, Central Java. Wayang golek santri show is performanced with figures Lupit and Slentheng [10]. Based on the description above, the purpose of this study was that the researcher analyzed the pattern of strengthening religious character through wayang golek santri performances, in terms of characters, story lines, settings, and messages contained therein. Wayang golek santri performances are expected to be one of the alternatives in strengthening religious character and become an appropriate medium in the community, especially teenagers who are vulnerable to adverse influences in social relations.

\section{Method}

This research was a content analysis research conducted using a qualitative approach. According to Wimmer \& Dominick content analysis research is a method for studying and analyzing communication systemically, objectively, and quantitatively to the messages that appear [11]. The choice of the type of content analysis research was because this research intends to uncover the contents of communication and test the hypothesis about the wayang golek santri performance message to the strengthening of religious character. The primary object in this research was the narrative of the story contained in the wayang golek santri recordings or video.

Meanwhile, secondary objects in this study include written documents such as textbooks, newspapers, and articles contained in various media. Data collection techniques used in this study were audio-visual techniques, documentation, and observation. Checking the validity of the data in this study was carried out using data triangulation techniques. Furthermore, the data obtained were analyzed by following the steps of the qualitative data analysis of the Miles and Huberman models. 


\section{Result And Discussion}

Wayang is walulang inukir (carved skin) whose shadow is seen on the screen [12]. Wayang is a world masterpiece containing various values such as ethics, spirituality, philosophy of life, music (gamelan music), to the aesthetics of complex art forms. Koitchiro Matsuura (Director of UNESCO 2004) said that wayang is recognized as one of the world's cultural heritages that must be preserved by all nations, especially the Indonesian people [13]. Wayang Golek is a puppet performance in the form of puppets made of wood carved, then given color and clothing [14]. Wayang golek santri itself is a puppet show which was coined by Ki Enthus Susmono as a means to spread the religion of Islam. Wayang santri was released in 2006 and was first staged at the Ki Enthus Susmono Hall, precisely in Bangle Village, Talang Sub District, Tegal Regency [15].

\subsection{Strengthening Religious Character Through Wayang Golek Santri Performance}

Wayang Santri considered to be able to strengthen the religious character through performances of artistic performances because the show carries themes that are close to the reality of life. Referring to the discussion which is identical to the strengthening of religious character, the researcher takes 3 Wayang Staging Themes which are then analyzed to see the meanings which indicate the strengthening of religious character in each of their performances. The three themes of the story in the wayang santri performances are as follows: "Samson Delilah", "Pethi Pandora", and Lupid Seneng Pitulung ". Religious attitudes have broad meanings. In the book on Penguatan Pendidikan Karakter or Strengthening Character Education, it is explained that religious sub-values include peace love, tolerance, respecting differences in religion and beliefs, firmness, self-confidence, cooperation between adherents of faith and beliefs, anti-bully and violence, friendship, sincerity, caring for other, loving the environment, protecting the small and marginalized [16]. Values that reflect the religious attitude contained in the dramatic conventions and central conventions in wayang santri shows.

\subsection{Religious Character Value in the Dramatic Convention of Wayang Golek Santri Performance}

Dramatic puppet conventions consist of story structure, character patterns, and the language used. The values of religious characters in the dramatic conventions of wayang santri shows are listed in the story structure and character patterns, which are as follows.

a. Story Structure.

Strengthening religious characters is contained in three themes of the story, including "Samson Delilah", "Pethi Pandora", and "Lupid Seneng Tetulung". Strengthening religious values that can be drawn from the stories above are as follows:

1) Firmness

The firmness value can be drawn from the story of Samson Delila. Sam'un who was caught by King Jalud, still believes firmly in religious teachings, namely by praying and asking for forgiveness and protection from God, even though he was tortured many times by Raja Jalud.

2) Peace of Love

The value of peace can be drawn from the story of Samson Delila and Lupit Nulung Putri. First, Sam'un or Samson always maintain peace in the Land of Rom from the cruel 
attitude of King Jalud. Samson also fought to crush all evil and kufr. Secondly, Kyai Ma'ruf, Lupit and Slentheng maintain peace by defeating the Garuda Demon because the Garuda Demon is did not let the people live in peace.

3) Sincerity

The value of sincerity in the wayang golek santri story can be quoted from the story "Peti Pandora", where Slentheng always guarded Lupit when he was sick, and did not leave Lupit when the enemy approached them, namely the Kepala Semangka and his bodyguards.

4) Cooperation

The value of cooperation is shown in the story "Lupit Nulung Putri". The cooperation was shown by Lupit and Slentheng when they were going to help Putri Tawangsih and Raja Badrun Qomari who were dumped by the Garuda Demon in the Tawang Uwuh Forest. They worked together to defeat the guards of Garuda Demon and Garuda Demon, by using the weapon "Wulu Gading" given by Kyai Ma'ruf.

5) Not Impose the Will

Value does not impose the will addressed in the story "Peti Pandora". The Kepala Semangka and his bodyguard will forcibly take the key of the Peti Pandora in Lupit's mouth, even though in reality, Peti Pandora is a non-existent object. The desire of the Kepala Semangka and his bodyguards to find out the whereabouts of Peti Pandora's key violates Lupit's right to live comfortably. The coercion of the will carried out by the Kepala Semangka and his bodyguards then causes a dispute which causes harm to themselves.

b. Character Pattern of Wayang Golek Santri

Strengthening religious values that can be inspired by the wayang golek santri character patterns include:

1) Kyai Ma'ruf, is a teacher and caregiver at the Banyu Bening Islamic Boarding School. Kyai Ma'ruf has a gentle, humble and high social minded feeling, especially to his students.

2) Lupit, is a santri / student of Kyai Ma'ruf at Banyu Bening Islamic Boarding School. Lupit diligently worships and is good at martial arts. The Lupit character in this story is someone who is cheerful, patient, calm and wise. Lupit has a high curiosity and often asks many questions to Slentheng.

3) Slentheng, is a santri / student of Kyai Ma'ruf in Banyu Bening Islamic Boarding School. Slenteng is a person whose religious knowledge is quite high. Slenteng always brings Lupit's curiosity about Islam. Slenteng characters are cheerful, humorous, cheerful, and sometimes beyond reason.

4) Sam'un Ghozi AS (Samson) or Sam'un is a Prophet who crushed the ignorance and kufr committed by King Jalud. Sam'un's characters are wise, peaceful, and determined.

5) Raja Badrun Qomari, is a King in Tawang Gantungan and a friend of Kyai Ma'ruf. King Badrun Qomari has a wise character, peace-loving and brave.

6) Putri Tawangsih, Putri Tawangsih is the daughter of King Badrun Qomari. Her beautiful face made the demon Garuda Sancaka want to marry her. The character of Putri Tawansih is that she loves peace, firmness and courage. Religious Character Values in the Central Convention of Wayang Golek Santri. 


\subsection{Religious Character Value in the Central Convention of Wayang Golek Santri Performance}

Central puppet conventions consist of time and place, equipment used, how to play, and gamelan (accompaniment music). The religious character values contained in the wayang golek central convention are as follows.

\section{a. Time and place}

Wayang santri shows are generally held at a place of celebration (held by people who have events) to commemorate various events, such as circumcisions, inauguration of buildings, etc. According to Burhan, for people who perceive wayang, wayang symbolizes God, meaning that without God's will, wayang performances will not occur [17]. God in power determines the place of the show, the location of the gamelan, puppet, and others.

\section{b. Equipment used}

The equipment used in wayang santri shows contains religious values that symbolize human relations with God, human relations with humans, and human relations with the natural surroundings. These objects include the following. 1) Wayang Golek santri came from Ki Enthus' desire to continue learning about Islam, so that if there were mistakes that he did not intentionally make, then these things must be corrected. 2) Gedebog as a place to plant a puppet is a symbol of the earth [18]. 3) Gawang kelir, is a place to play wayang: In wayang santri performances, the frame or kelir is shaped like a gawang or goal posts. The kelir in the puppet show symbolizes the universe and the kayon standing in the middle symbolize the universe [19].

\section{c. The Way to Play the puppet}

The puppeteer or dalang is the main actor in the puppet show because the puppeteer is a person who works full time during the performance. The puppeteer is considered as executing God's commands. Puppeteers in wayang santri show a responsible attitude and cooperation.

\section{d. Accompanying Gamelan Music}

Gamelan symbolizes the lives of humans and other creatures [21]. The accompanying songs in puppet puppet performances are more likely to use the song of the sholawat which is the result of the creativity of Ki Enthus and his team. According to Burhan, in the wayang performance, the rhythm of the song used is divided into four parts: 1) The first part symbolizes the nature of children who tend to still like to do things that are wrong; 2) The second part symbolizes the nature of adult humans who tend to like to do right and wrong; 3) The third part symbolizes human nature which tends to be more like doing right and doing less wrong; and 4) The last part symbolizes that human life has ended and returned to the bosom of God. [22]. Based on this theory, the puppet has meaning in terms of religious life, human life consists of three relationships, namely human relations with God, human relations with humans, and human relations with humans.

\section{Conclusion}

Religious strengthening through wayang golek santri performances contained in aspects of dramatic conventions and central conventions. Dramatic conventions are story structures and character patterns. The structure of the story in the wayang santri stage which contains religious values is contained in the story of Samson Delilah, Peti Pandhora, and Lupit Nulung Putri. Religious values that can be quoted from the three stories include a firm attitude, love 
for peace, sincerity, cooperation, and not implement the will. Meanwhile, religious values can be quoted from the role of wayang santri figures including Lupit, Slentheng, Kyai Ma'ruf, Sam'un Ghozi AS (Samson), Raja Badrun Qomari, and Putri Tawangsih. Furthermore, the central convention consists of time and place, equipment used, how to play, and gamelan / accompaniment. Religious values contained in the aspects of time and place are more directed as a form of gratitude to God for the implementation of certain celebrations.

Secondly, in the aspect of santri equipment, it contains religious values that symbolize the human relationship with God, human relations with humans, and human relations with the natural environment in the form of objects, such as wayang santri who always study religion, debog symbolizing the earth, and the gawang kelir symbolizing the universe. Third, the dalang or puppeteer is considered as executing God's commands. Puppeteers in wayang golek santri performance show a responsible attitude and cooperation. Fourth, gamelan symbolizes the lives of humans and other creatures.

\section{References}

[1] Darmiyati Z, Pendidikan Karakter (Konsep Dasar dan Implementasi di Perguruan Tinggi). Yogyakarta: UNY Press, 2012

[2] Al S, Penembakan di Sekolah AS: Dua Siswa Tewas, Pelaku Remaja Introver yang "Cerdas". Diakses dari https://www.bbc.com/indonesia/dunia-50428912 pada tanggal 25 Juli 2020 pukul 08.14 .

[3] P Kurniati, "4 Kasus "Bullying" di Sejumlah Daerah, Dibanting ke Paving, Amputasi hingga Korban Depresi Berat". Diakses dari https://regional.kompas.com/read/2020/02/08/06060081/4kasus-bullying-di-sejumlah-daerah-dibanting-ke-paving-amputasi-hingga?page=all. Pada tanggal 25 Juli 2020 pukul 08.17.

[4] Welch, M. R., Sikkink, D., Sartain, E., \& Bond, C, "Trust in God and trust in man: the ambivalent role of religion in shaping dimensions of social trust," Journal for the Scientific Study of Religion, 43, 317-343, 2004.

[5] Putnam, R.D., \& Campbell, D.E, American grace: how religion divides and unites us. New York, NY: Simon \& Schuster, 2010.

[6] Hasan, S.H, Pengembangan Pendidikan Budaya dan Karakter Bangsa. Jakarta: Badan Penelitian dan Pengembangan Pusat Kurikulum, 2010

[7] Lisa D. Pearce, George M. Hayward, \& Jessica A. Pearlman, Measuring Five Dimensions of Religiosity Across. Review of Religious Research, 59, 367-393, 2017

[8] Kemendikbud, Konsep dan Pedoman Penguatan Pendidikan Karakter (Buku 1). Jakarta: Kementerian Pendidikan dan Kebudayaan, 2017

[9] Majid, Novita, Penguatan Karakter Melalui Local Wisdom sebagai Budaya Kewarganegaraan. Sulawesi Selatan: Yayasan Ahmar Cendekia Indonesia, 2019

[10] Suripto, Imam, Di Brebes, Pelajar SMA Dapat Pendidikan Karakter Lewat Wayang Golek. Diakses dari https://news.detik.com/berita-jawa-tengah/d-3851134/di-brebes-pelajar-sma-dapatpendidikan-karakter-lewat-wayang-golek pada tanggal 07 Februari 2020 pukul 14.58

[11] Suyanto, Bagong \& Sutinah (ed), Metode Penelitian Sosial berbagai Alternatif Pendekatan. Jakarta: Kencana Prenada Media Group, 2005.

[12] Sri M, Wayang, Asal-usul, Filsafat, dan Masa Depannya. Jakarta: CV Haji Masagung, 1989

[13] Sudjarwo, Heru S, Sumari, \& Undung Wiyono, Rupa \& Karakter Wayang Purwa. Jakarta: Kakilangit Kencana Prenada Media Group, 2010

[14] Sekretariat Nasional Pewayangan Indonesia, Ensiklopedi wayang Indonesia: C-J Jilid 2 dari Ensiklopedi wayang Indonesia. Jakarta: Sena Wangi, 1999

[15] Anisul F \& Apit N, "Strategi Dakwah Wayang Santri Ki Enthus Susmono,"Jurnal Dakwah dan Komunikasi, 8 (2), 29-42, 2017 
[16] Kemendikbud, Konsep dan Pedoman Penguatan Pendidikan Karakter (Buku 1). Jakarta: Kementerian Pendidikan dan Kebudayaan, 2017

[17] Burhan N,"Wayang dan Pengembangan Karakter Bangsa,” Jurnal Pendidikan Karakter, 1 (1), 19-34, 2011

[18] Tuti S, Semar, Dunia Batin Orang Jawa. Yogyakarta: Galang Press, 2006

[19] Tuti S, Semar, Dunia Batin Orang Jawa. Yogyakarta: Galang Press, 2006

[20] H Amir, Nilai-nilai Etis dalam Wayang. Jakarta: Sinar Harapan, 1994.

[21] Tuti S, Semar, Dunia Batin Orang Jawa. Yogyakarta: Galang Press, 2006

[22] Burhan N,"Wayang dan Pengembangan Karakter Bangsa," Jurnal Pendidikan Karakter, 1 (1), $19-34,2011$ 